\title{
Protective Effects of Tribulus terrestris Hydroalcoholic Extract Against Cisplatin-Induced Germ Cell Apoptosis in Male Mice
}

\author{
Efectos Protectores del Extracto Hidroalcohólico Tribulus terrestris Contra la \\ Apoptosis de Células Germinales Inducida por Cisplatino en Ratones Machos
}

\author{
Keshtmand Zahra
}

KESHTMAND, Z. Protective effects of Tribulus terrestris hydroalcoholic extract against cisplatin-induced germ cell apoptosis in male mice. Int. J. Morphol., 36(1):140-144, 2018.

SUMMARY: Toxic effects of anti-cancer and other drugs on the normal tissues could be reduced by the herbal plants and their fractions. This study investigated the protective effect of Tribulus terrestris (TT) on Cisplatin- induced cytotoxicity germ cell apoptosis in male mice. In this experimental study, thirty male Balb/c mice were divided randomly into 5 groups $(\mathrm{n}=6)$. A single dose of Cisplatin $(5.5 \mathrm{mg} / \mathrm{kg}$ ) and differ-ent concentrations of Tribulus terrestris were administrated for 14 consecutive days. Reverse transcription polymerase chain reaction (RT-PCR) of apoptosis-re-lated genes was performed with RNA extracted from testes of the mice. Statistical analysis was done using one-way ANOVA. In the Cisplatin group, there was a significant increase in mRNA expression of $p 53$ ( $\mathrm{P}=0.008$ ), bax $(\mathrm{P}=0.004)$ and the ratio of $b a x / B c l-2(\mathrm{P}=0.000)$, whereas there was an decrease in the expression of $B c l-2(\mathrm{P}=0.003)$, as compared to control group. In Cis $+T T$ groups, the data showed that different concentrations of $T T$ could improve the harmful effects caused by the Cisplatin. The best protective effects were achieved in Cis $+T T(300 \mathrm{mg} / \mathrm{kg})$. Tribulus terrestris protects testicular germ cell against Cisplatin induced apoptosis by affecting related genes regulation.

KEY WORDS: Apoptosis; Cisplatin; Tribulus terrestris; Mice; Germ Cells.

\section{INTRODUCTION}

Cisplatin (cis-Diamminedichloroplatinum (II): CDDP) is actually one of the most widely used anticancer drugs, and the central role of this drug in human cancer chemotherapy aTTests to its current importance (Sedletska et al., 2005). Cisplatin-based chemotherapy is highly efficient for the treatment of patients with a variety of cancers such as lung, ovarian, head and neck, and gastric cancer (Frezza et al., 2010).

On the other hand, its trans analogue, transplatin, is known to be biologically inactive because of the diversity of qualitative and quantitative DNA adducts that it forms compared with cisplatin (Zhang et al., 2010).

CDDP has proven to be one of the more efficient anticancer chemotherapeutic agents because it targets multiple intracellular sites in order to induce death in tumor cells (Olszewski \& Hamilton, 2010). p53 is involved in the activation of apoptosis induced by DNA-damage, such as cisplatin (Brozovic et al., 2010). As a transcriptional activator, $p 53$ increases the transcription of a number of genes and the paTTern of transcriptional regulation is critical in determining the cellular response to DNA damage (Kanter et al., 2005; Woo et al., 2012). It is known to activate the transcription of death agonist, bax, but to repress the expression of death antagonist, bcl- 2 Given the roles of $\mathrm{Bcl}$ 2 , bax and $p 53$ in cell death and survival, we examined the expression of these genes. Studies in mice have shown that ROS generation mediated by sodium selenite is associated with expression of $p 38, B c l-2$, Caspases 3 and 8 (Matsumoto et al., 2016).

$\mathrm{Bcl}-2$ family of proteins is the regulation of cytochrome $\mathrm{c}$ release from the mitochondria via alteration of mitochondrial membrane permeability (Vaux et al., 1992).

In the past, medicinal plants were considered as the only form of health care readily available to the majority of human population (WHO, 2000). At present, it is estimated that about $80 \%$ of the world population relies on botanical preparations as medicine to meet their health needs (Mathur, 2003). In recent years, in view of their beneficial effects, 
the use of spices and herbs has been gradually increasing in developing countries. Tribulus terrestris is a member of the plant family Zygophillaceae. The fruit is regarded as tonic, diuretic and aphrodisiac. It is also used to treat urinary disorders, impotence and heart disease. The seeds are recommended in hemorrhages, kidney stone and gout (Shinwari \& Khan, 2000). The extract of $T T$ contains protodioscin (PTN), a steroidal saponin that has been extensively used for the treatment of various ailments, such as urinary (Wang et al., 1999) and cardiovascular (Joshi et al., 2005) disorder. Administration of TT in human and animals improves libido and spermatogenesis (Gauthaman et al., 2003). TT has a projectile effect (Martino-Andrade et al., 2010). Tribulus terrestris extract contains many compounds such as alkaloids, flavonoid oils, saponins, resins and nitrates (Gauthaman \& Ganesan, 2008).

\section{MATERIAL AND METHOD}

Experimental design. In this experimental study, thirty male Balb/c mice aged 10 weeks $(30 \pm 2 \mathrm{~g})$ were obtained from a closed bred colony at Kermanshah University of Medical Sciences, Kermanshah, Iran. The animals received care as recommended by the Ethics Research CommiTTee of the Kermanshah University of Medical Sciences (EC/KNRC/ 90-4) in accordance with the internationally accepted principles for laboratory animal use and care, as found in the European Community guidelines (EEC Directive of $1986 ; 86 / 609 / E E C$ ) or US guidelines (NIH publication \#8523 , revised in 1985). The mice were maintained on a regular diet and water at a $12: 12$ hour light/dark cycle at $23{ }^{\circ} \mathrm{C} \pm$ $2{ }^{\circ} \mathrm{C}$. Experiment was started after one week adaptation. The animals were divided randomly into following 5 groups $(n=6)$ i: Control group receiving normal saline, ii. Experimental group (E1) receiving only an intraperitoneal single dose injection of Cisplatin ( $20 \mathrm{mg} / \mathrm{kg}$; Sigma Aldrich, USA), iii. Experimental groups (E2-E4) receiving an intraperitoneal injection of Cisplatin $(20 \mathrm{mg} / \mathrm{kg})$ plus terribulus terrestris (Sigma Aldrich, USA) in different concentrations of $100 \mathrm{mg}$ / $\mathrm{kg}$ (E2), $300 \mathrm{mg} / \mathrm{kg}$ (E3), and $500 \mathrm{mg} / \mathrm{kg}$ (E4) for 14 consecutive days (Fouda et al., 2008). On the day final, the mice were sacrificed by cervical dislocation.

Reverse transcription-polymerase chain reaction analysis. RNA was extracted from testes tissues using the RNAeasy Plus Mini Kit (Qiagen, Germany), including a gDNA Eliminator column to avoid DNase digestion and a RNeasy Mini Spin columns to purify RNA samples. Total RNA $(\leq 1 \mu \mathrm{g})$ was reverse transcribed using a poly $\mathrm{T}$ tail primer included in the One Step RT-PCR Kit (Qiagen, Germany). cDNA was amplified according to the manufacturer's instructions. Primer pairs, amplicon sizes, and annealing times are shown in Table I. Cycle conditions were as follows: denaturation at $95{ }^{\circ} \mathrm{C}$ for 15 minutes that was followed by 30 cycles at $94^{\circ} \mathrm{C}$ for 60 seconds, annealing at $58{ }^{\circ} \mathrm{C}$ to $60{ }^{\circ} \mathrm{C}$ for 60 seconds, and elongation at $72{ }^{\circ} \mathrm{C}$ for 60 seconds, with a final cycle at $72{ }^{\circ} \mathrm{C}$ for 10 minutes. Experiments were performed in triplicate to ensure reproducibility. Products were electrophoresed on a $1.5 \%$ agarose gel. Gels were stained with ethidium bromide (10 $\mu \mathrm{g} / \mathrm{ml}$ ) and photographed on an ultraviolet (UV) transilluminator (UVIdoc, Uvitec, UK). Gel images were analyzed using the UV image (UVI) band map program (Uvitec, UK). Primers characteristics are listed in Table I.

RT-PCR values were presented as a ratio of the specified gene signal divided by the glyceraldehyde-3phosphate dehydrogenase (GAPDH) signal. RT-PCR was performed as three individual replicates (Koike et al., 2007).

Statistical analysis. All data were analyzed by one-way ANOVA followed by Tukey's test using SPSS (SPSS Inc., USA) software. Results are expressed as the mean \pm SEM, and $\mathrm{P}<0.05$ was considered significant.

\section{RESULTS}

The expression of markers. The expression levels of markers and profiles of the relative expression levels are shown in Figures 1 and 2. In the E2 group, there was a

Table I. Primers used for RT-PCR applied for apoptosis-related gene expression in testis of mice.

\begin{tabular}{|c|c|c|c|}
\hline Gene & Forward sequence Reverse sequence & Annealing temprature ("C) & Product Size (bp) \\
\hline \multirow[t]{2}{*}{ GAPDH } & 5'- TGCCCCCATGTTTGTGATG-3' & 66 & 151 \\
\hline & 5'-TGTGGTCATGAGCCCTTCC-3' & & \\
\hline \multirow[t]{2}{*}{ Bax } & 5'- GCTGATGGCAACTTCAACTG-3' & 61 & 99 \\
\hline & 5'- GATCAGCTCGGGCACTTTAG -3' & & \\
\hline \multirow[t]{2}{*}{ Bcl-2 } & 5'- AGCGTCAACAGGGAGATGTC -3' & 63 & 120 \\
\hline & 5'- TTCCACAAAGGCATCCCAGC-3' & & \\
\hline \multirow[t]{2}{*}{ P53 } & 5'- AGAGACCGCCGTACAGAAGA-3' & 61 & 227 \\
\hline & 5'- GCATGGGCATCCTTTAACTC-3' & & \\
\hline
\end{tabular}


significant decrease in expression of bcl2 ( $\mathrm{P}=0.003)$, whereas there was a significant increase in the expression levels of other markers, including $p 53(\mathrm{P}=0.008$ and $\operatorname{bax}(\mathrm{P}=0.004)$. The ratio of bax/bcl2 also increased in $\mathrm{E} 1$ group $(\mathrm{P}=0.000)$.
The expression levels of these markers in Cis+TT groups (E2E4) were between the related values of E1 and control groups. Furthermore, the expression level of bcl2 significantly decreased in $\mathrm{E} 2(\mathrm{P}=0.002)$ and $\mathrm{E} 3$ groups $(\mathrm{P}=0.005)$.
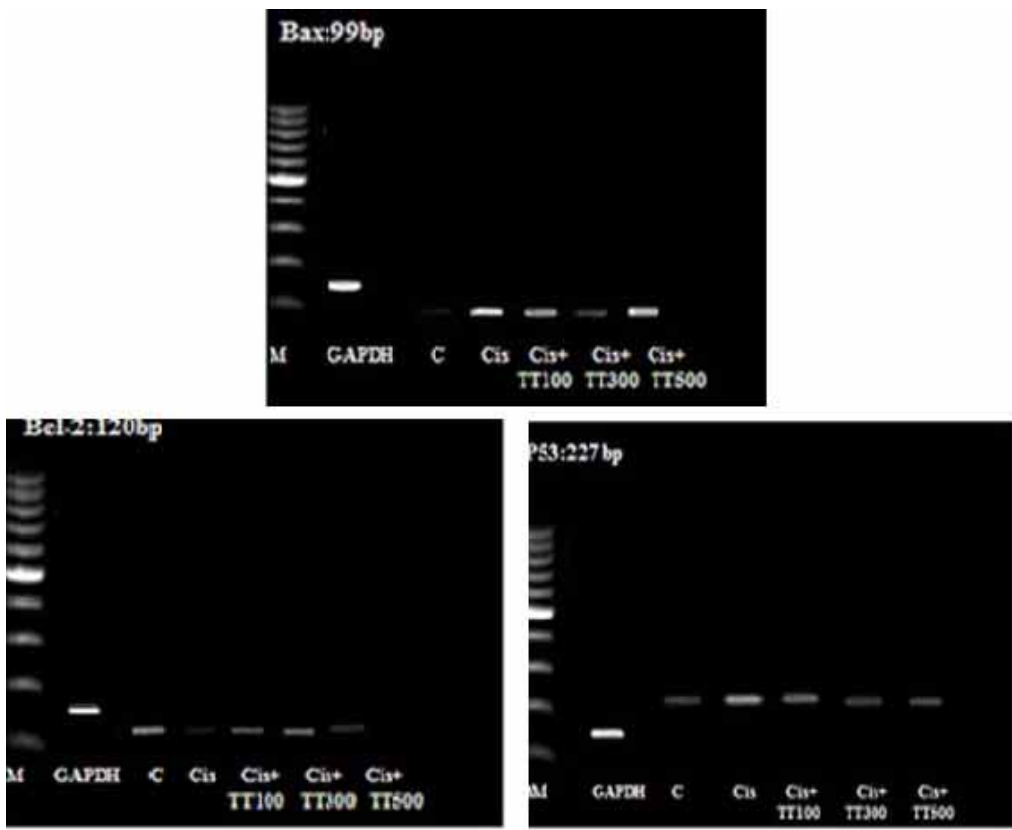

Fig. 1. Temporal expression pattern of genes in testis of mice treated with Cis plus different concentrations of TT using by reverse transcription polymerase chain reaction (RT-PCR) in 4 experimental groups (E1-E4). Cis; Cisplatin and TT: Teribulus terrestris.
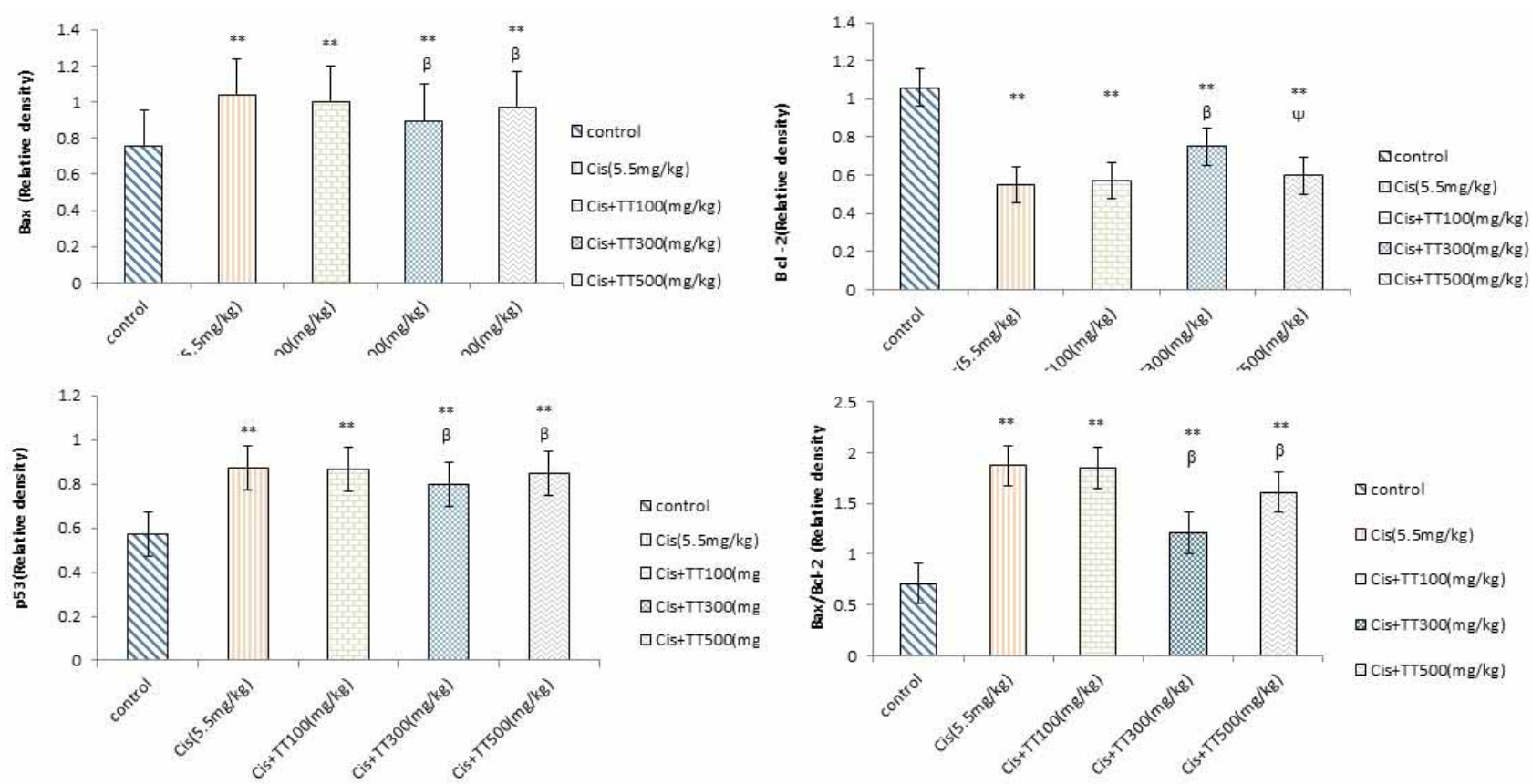

Fig. 2. Expression of related genes of apoptosis in testis of mice treated with Cis plus different concentrations of TT using RT-PCR in 4 experimental groups (E1-E4). The differences between groups are presented by ANOVA. All the values are expressed as mean \pm SEM. Cis; Cisplatin and TT: Tibullus terrestris., RT-PCR; Reverse transcription polymerase chain reaction. **; $\mathrm{P}<0.01$, **; $\mathrm{P}<0.01$ compare to control group, $\mathrm{b} ; \mathrm{P}<0.01$ and $\mathrm{y} ; \mathrm{P}<0.001$ compare to Cis group. 


\section{DISCUSSION}

In the present study, the percentage of apoptotic cells was found to be increased after Cisplatin treatment. It has been further reported cisplatin induced apoptosis in the hepatocytes of rats, which can be aTTributed to the nucleotide pool imbalance or the repression of the c Jun N-terminal kinase (JNK) activity and up regulation of p53 and p21 (Kobayashi et al., 2002).

Consistent with these results, our study showed that administration of Cisplatin induced testicular damage characterized by seminiferous tubule degeneration and apoptosis of germ cells via both $p 53$ and $\mathrm{Bax} / \mathrm{Bcl}-2$ pathways. The release of cytochrome $\mathrm{c}$ from mitochondria has been indicated to be a critical step in the activation of the caspase protease cascade. Caspases trigger a cascade of proteolytic cleavage events that are considered as central players in all apoptotic events in mammals. $B c l-2$ and $B c l-x$ (L) inhibit apoptosis, in part by blocking the release of cytochrome $\mathrm{c}$ from mitochondria. On the contrary, other family members, such as bax and bad, interfere with the activity of $\mathrm{Bcl}-2$ by binding to them and generating a nonfunctional unit (Leisching et al., 2015).

Cisplatin has a clinical activity against various solid tumors. The effectiveness of chemotherapy with Cisplatin is restricted by the emergence of resistant cell populations, and defining of the molecular features that determine the resistance to Cisplatin has an important clinical implication (Brozovic et al.).

The recent evidence suggests that the genetic regulation of apoptosis may affect the cellular response to DNA damages and, therefore, modulate the sensitivity of tumor cells to Cisplatin p53 tumor suppressor gene is most commonly mutated in human cancers (Sedletska et al.). It is recognized as an important component of the pathway leading from DNA damage to apoptosis and several studies have suggested that p53 is involved in the activation of apoptosis induced by DNAdamaging anticancer agents (Park et al., 2006). Introduction of DNA strand breaks leads to a post- transcriptional increase in $p 53$ protein levels. In this study, we examined in vitro selected cisplatin resistant sublines made by the continuous exposure of Cisplatin. We expected the increase in the level of $p 53$ protein of these resistant sublines by cisplatin induced DNA- damage Although p53 is known to transactivate bax, it suppresses $b c l-2$ expression and the magnitude of $p 53$ suppression of $b c l$ - 2 expression may be tissue-specific .

Present study showed that Tribulus terrestris prevented apoptosis in seminiferous tubules treated with Tribulus terrestris through affecting mRNA expression levels of P53 as well as the $B a x / B c l-2$ ratio.

These results are consistent with previous report that showed combination of Tribulus terrestris and conventional chemotherapeutic drugs could produce greater therapeutic effect as well as reduce the toxicity of the laTTer.

\section{CONCLUSION}

Combination of Tribulus terrestris with chemotherapeutic agents may provide a novel therapeutic approach. However, further research in animal models is warranted to obtain more conclusive evidence for the molecular basis of Tribulus terrestris action. Despite its therapeutic efficacy in tumor cell lines and animal models, the data on bioavailability and other pharmacokinetic parameters of Tribulus terrestris are still incomplete.

ACKNOWLEDMEMENTS. I acknowledge the staff of Fertility and Infertility Research Center of Kermanshah.

KESHTMAND, Z. Efectos protectores del extracto hidroalcohólico Tribulus terrestris contra la apoptosis de células germinales inducida por cisplatino en ratones machos. Int. J. Morphol., 36(1):140144,2018

RESUMEN: Los efectos tóxicos en los tejidos normales, de los medicamentos contra el cáncer al igual que otras medicamentos podrían mejorar con el uso de plantas medicinales y hierbas. Este estudio investigó el efecto protector de Tribulus terrestris (TT) sobre la apoptosis de células germinales por citotoxicidad inducida por cisplatino en ratones machos. En este estudio se dividieron treinta ratones Balb/c macho aleatoriamente en 5 grupos $(n=6)$. Se administró una sola dosis de cisplatino $(5,5 \mathrm{mg} / \mathrm{kg})$ y diferentes concentraciones de Tribulus terrestris durante 14 días consecutivos. La reacción en cadena de la polimerasa de transcripción reversa de los genes relacionados con la apoptosis, se realizó con ARN extraído de los testículos de los ratones. El análisis estadístico se realizó usando ANOVA de una vía. En el grupo cisplatino, hubo un aumento significativo en la expresión de mRNA de $p 53(\mathrm{P}=0,008)$, bax $(\mathrm{P}=0,004)$ y la relación de bax / Bcl-2 $(\mathrm{P}=0.000)$, mientras que hubo una disminución en la expresión de $B c l-2(\mathrm{P}=0,003)$, en comparación con el grupo control. En los grupos Cis $+T T$, los datos mostraron que las diferentes concentraciones de TT podrían mejorar los efectos nocivos causados por el cisplatino. Los mejores efectos protectores se lograron en Cis + TT (300 mg / kg). Tribulus terrestris protege las células germinales testiculares contra la apoptosis inducida por cisplatino al afectar la regulación de los genes relacionados.

PALABRAS CLAVE: Apoptosis; Cisplatino; Tribulus terrestris; Ratones; Células germinales. 


\section{REFERENCES}

Brozovic, A.; Ambriovic-Ristov, A. \& Osmak, M. The relationship between cisplatin-induced reactive oxygen species, glutathione, and $B C L-2$ and resistance to cisplatin. Crit. Rev. Toxicol., 40(4):347-59, 2010.

Fouda, A. M.; Daba, M. H.; Dahab, G. M. \& Sharaf El-Din, O. A. Thymoquinone ameliorates renal oxidative damage and proliferative response induced by mercuric chloride in rats. Basic Clin. Pharmacol. Toxicol., 103(2):109-18, 2008.

Frezza, M.; Hindo, S.; Chen, D.; Davenport, A.; SchmiTT, S.; Tomco, D. \& Dou, Q. P. Novel metals and metal complexes as platforms for cancer therapy. Curr. Pharm. Des., 16(16):1813-25, 2010.

Gauthaman, K. \& Ganesan, A. P. The hormonal effects of Tribulus terrestris and its role in the management of male erectile dysfunction--an evaluation using primates, rabbit and rat. Phytomedicine, 15(1-2):4454,2008

Gauthaman, K.; Ganesan, A. \& Prasad, R. N. Sexual effects of puncturevine (Tribulus terrestris) extract (protodioscin): an evaluation using a rat model. J. Altern. Complement. Med., 9(2):257-65, 2003.

Joshi, V. S.; Parekh, B. B.; Joshi, M. J. \& Vaidya, A. D. Inhibition of the growth of urinary calcium hydrogen phosphate dihydrate crystals with aqueous extracts of Tribulus terrestris and Bergenia ligulata. Urol. Res., 33(2):80-6, 2005.

Kanter, M.; Coskun, O. \& Budancamanak, M. Hepatoprotective effects of Nigella sativa $L$ and Urtica dioica $L$ on lipid peroxidation, antioxidant enzyme systems and liver enzymes in carbon tetrachloride-treated rats. World J. Gastroenterol., 11(42):6684-8, 2005.

Kobayashi, K.; Terada, C. \& Tsukamoto, I. Methotrexate-induced apoptosis in hepatocytes after partial hepatectomy. Eur. J. Pharmacol., 438(12): 19-24, 2002.

Koike, M.; Sakaki, S.; Amano, Y. \& Kurosawa, H. Characterization of embryoid bodies of mouse embryonic stem cells formed under various culture conditions and estimation of differentiation status of such bodies. J. Biosci. Bioeng., 104(4):294-9, 2007.

Leisching, G.; Loos, B.; Botha, M. \& Engelbrecht, A. M. Bcl-2 confers survival in cisplatin treated cervical cancer cells: circumventing cisplatin dose-dependent toxicity and resistance. J. Transl. Med., 13:328, 2015.

Martino-Andrade, A. J.; Morais, R. N.; Spercoski, K. M.; Rossi, S. C.; Vechi, M. F.; Golin, M.; Lombardi, N. F.; Greca, C. S. \& Dalsenter, P. R. Effects of Tribulus terrestris on endocrine sensitive organs in male and female Wistar rats. J. Ethnopharmacol., 127(1):165-70, 2010.

Mathur, S. J. N. Ginger: Its role in xenobiotic metabolism. ICMR Bull., 3(6):57-8, 2003.

Matsumoto, M.; Nakajima ,W.; Seike, M.; Gemma, A. \& Tanaka, N. Cisplatin-induced apoptosis in non-small-cell lung cancer cells is dependent on Bax- and Bak-induction pathway and synergistically activated by BH3-mimetic ABT-263 in p53 wild-type and mutant cells. Biochem. Biophys. Res. Commun., 473(2):490-6, 2016.

Olszewski, U. \& Hamilton, G. A beTTer platinum-based anticancer drug yet to come? Anticancer Agents Med. Chem., 10(4):293-301, 2010.

Park, C. M.; Park, M. J.; Kwak, H. J.; Moon, S. I.; Yoo, D. H.; Lee, H. C.; Park, I. C.; Rhee, C. H. \& Hong, S. I. Induction of $p 53$-mediated apoptosis and recovery of chemosensitivity through $p 53$ transduction in human glioblastoma cells by cisplatin. Int. J. Oncol, 28(1):119-25, 2006.

Sedletska, Y.; Giraud-Panis, M. J. \& Malinge, J. M. Cisplatin is a DNAdamaging antitumour compound triggering multifactorial biochemical responses in cancer cells: importance of apoptotic pathways. Curr. Med. Chem. Anticancer Agents, 5(3):251-65, 2005.

Shinwari, M. I. \& Khan, M. A. Folk use of medicinal herbs of Margalla Hills National Park, Islamabad. J. Ethnopharmacol., 69(1):45-56, 2000.

Vaux, D. L.; Weissman, I. L. \& Kim, S. K. Prevention of programmed cell death in Caenorhabditis elegans by human Bcl-2. Science, 258(5090):1955-7, 1992.
Wang, R.; Monga, M. \& Hellstrom, W. J. G. Ejaculatory Dysfunction. In: Comhaire, F. H. (Eds.). Male Infertility Clinical Investigation Causes Evaluation and Treatment. London, Champan and Hall Medical, 1999.

Woo, C. C.; Kumar, A. P.; Sethi, G. \& Tan, K. H. Thymoquinone: potential cure for inflammatory disorders and cancer. Biochem. Pharmacol., 83(4):443-51, 2012

World Health Organization (WHO). General Guidelines for Methodologies on Research and Evaluation of Traditional Medicines. Geneva, World Health Organization, 2000. pp.33-7.

Zhang, J.; Wang, L.; Xing, Z.; Liu. D.; Sun, J.; Li, X. \& Zhang, Y. Status of bi- and multi-nuclear platinum anticancer drug development. Anticancer Agents Med. Chem., 10(4):272-82, 2010.

\section{Corresponding author \\ Keshtmand Zahra \\ Department of Biology \\ Central Tehran Branch \\ Islamic Azad University \\ Tehran \\ IRAN}

Email: zkeshtmand2001@yahoo.com

Received: 03-07-2017

Accepted: 30-09-2017 